\title{
REVIEW OF EXISTING AND NEW LONG-TERM HOUSING FINANCIAL INSTRUMENTS IN LATVIA
}

\author{
Inita Henilane \\ BA School of Business and Finance, K. Valdemara street 161, Riga, Latvia \\ E-mails: inita.henilane@ba.lv; initahenilane5@inbox.lv
}

\begin{abstract}
The purpose of the study is to identify the existing and new long-term housing financial instruments in Latvia. Principal objectives are: to evaluate the experience of the implementation of existing housing support programmes in Latvia; to describe the existing and new housing financial instruments in EU countries; to develop the list of new long-term housing financial instruments suitable for Latvia. Scope of investigation is housing financial instruments. Research methodology: Analytic research method and comparative research method. Results and principal conclusions: The results of the research show that government of Latvia should evaluate which of new long-term financial instruments should be implemented in housing sector in Latvia.
\end{abstract}

Keywords: housing, energy efficiency, financial instruments, housing policy, housing programmes, Latvia.

JEL Classification: G21; H81; $018 ; \mathrm{R} 31$.

\section{Introduction}

The biggest problem in housing sector in Latvia is unsatisfactory technical condition of multi-apartment buildings, because the most part of all multiapartment buildings were built during the Soviet period, which are characterized by construction technologies incompliance with modern requirements and other aspects what according to modern requirements require renewal and transformation of housing infrastructure. However, the problems have not yet reached results improving the general housing situation, because there are required significant investments in the long term (Henilane 2015a). For solving the problem the governmet of Latvia should have to look for new ways to attract the investments and to implement new financial instruments for long term in housing sector.

There are limited number of researches in the housing sector in Latvia in general. Hovewer the topical researches has been done by different authors (e.g. Sidelska 2014; Geipele 2014; Ikjevleva 2014; Ruza 2012; Geipele et al. 2012; Henilane $2015 \mathrm{~b}$ and etc.)

The purpose of the study is to identify the existing housing financial instruments and evaluate possibilities of the implementation of new longterm housing financial instruments in Latvia.

The research paper is structured in three parts. In the first part there are characterized the results of the implementation of existing housing support programmes in Latvia from 2000-2016. In the second part there are analyzed the existing and new housing financial instruments for energy efficiency measures in housing sector in EU countries. In the third part there are developed proposals of the new long-term housing financial instruments suitable for Latvia.

Scope of investigation is housing financial instruments.

In conclusion are made proposals for the government of Latvia in context with the development of new financial instruments.

In research paper are applied the analytical research method and comparative research method.

\section{Evaluation of the implementation of housing support programmes for Latvia}

According to National Real Estate Cadastre Information System data, by total area of the housing stock the majority of housing stock - 60\% is formed by multi-apartment buildings ( 52.3 million square metres) and 40 per cent - single-dwelling buildings (33.5 million square metres) in Latvia. The majority or $89 \%$ of all multi-apartment buildings were built during the Soviet era, and do not comply with modern requirements in terms of applied construction technologies and building materials, as well as from the perspective of construction laws and regulations, and thus it has left long- 
term adverse effects to the technical condition and maintenance costs of multi-apartment buildings. Following the restoration of the Republic of Latvia in 1990, when the transition to market economy was announced, one of the reform measures in the housing sector was refusal of state to finance the construction of multi-apartment buildings from the state budget and to subside their maintenance what negatively affected overall housing situation in the country. After that capital investments in the construction of multi-apartment buildings are based on private sector investments, but local governments invest in construction of social houses (Central Statistical Bureau database; Ekonomikas ministrijas 2013; Henilane 2015c; Riga Technical University 2013).

Despite the fact that the Latvian housing sector is characterized by poor condition of multiapartment buildings, there have been implemented several housing support programmes in this area, as well as there was provided also support to different social groups to promote crediting for purchase of housing and for energy efficiency measures (see Table 1).

As the majority of all multi-apartment buildings were built during the Soviet era, their lifetime is about 60-70 years (Henilane 2015c; Ministru kabineta... 2010).
Taking into account the above mentioned about the medium lifetime of multi-apartment buildings and the investments which are made up to this and planned investments in multi-apartment building sector, author concludes it is necessary to find out new possibilities to attract financial resources to the multiapartment sector. One of the main solutions is to find out new financial instruments with help of which it would be possible to attract private investments in long-term, and thus to improve common condition of multi-apartment building sector in the country in general.

Simultaneously the state government in cooperation with local governments and private sector should look for solutions in order to support various types of housing for social groups (for example, for young families, families with more than three children, students, etc.), in order to provide them with qualitative housing.

\section{Financing instruments for energy efficiency measures in housing in EU countries}

In order to improve energy efficiency in buildings and decrease of consumed energy thereof the essential importance plays reaching the mutually related sustainability goals defined in European strategy "Europe 2020" and "European Energy

Table 1. Housing support programme implementation results in Latvia, 2000-2016 (Source: developed by author by data of Ministry of Environmental... 2003; Ministru kabineta... 2002; Ministru kabineta ... 2008; Ministru kabineta... 2013; Ekonomikas ministrija 2015a; Ekonomikas ministrija 2015b; Ekonomikas ministrija 2014)

\begin{tabular}{c|l|l}
\hline \multicolumn{1}{c|}{ Programme } & Programme funding & \multicolumn{1}{c}{ Programme results } \\
\hline $\begin{array}{l}\text { 1. Housing development lending pro- } \\
\text { gramme, Stage I (2000-2002) }\end{array}$ & $\begin{array}{l}35,57 \text { million euro; } \\
\text { dollars }\end{array}$ & $\begin{array}{l}\text { - Issued 52 loans for multi-apartment building } \\
\text { renovation, total amount - 1,02 million euro } \\
\text { - Issued 2202 mortgage loans for private persons } \\
\text { for purchase or renovation of dwelling, total } \\
\text { amount - 11,03 million euro }\end{array}$ \\
\hline $\begin{array}{l}\text { 2. Housing development lending pro- } \\
\text { gramme, Phase 2 (2002-2008) }\end{array}$ & 0,78 million euro & $\begin{array}{l}\text { - Issued 177 guarantees for housing loans for } \\
\text { families, total amount of 2,7 million euro } \\
\text { - Issued 4 guarantees for housing loans for dena- } \\
\text { tionalized houses and their family members in } \\
\text { amount of 72 thousand euro for the purchase or } \\
\text { construction of dwelling }\end{array}$ \\
\hline $\begin{array}{l}\text { 3. EU programme "Improvement of } \\
\text { heat insulation of multi-apartment } \\
\text { residential buildings" (2007-2013) }\end{array}$ & 81,3 million euro & $\begin{array}{l}\text { Insulated 666 multi-apartment houses and 92 pro- } \\
\text { jects are in implementation stage (by 12.2015.) }\end{array}$ \\
\hline $\begin{array}{l}\text { 4. EU programme "Improvement of } \\
\text { heat insulation of social residential } \\
\text { buildings" (2007-2013) }\end{array}$ & 9,2 million euro & Insulated 55 social houses \\
\hline $\begin{array}{l}\text { 5. States support programme for fam- } \\
\text { ilielies for purchase of the first } \\
\text { housing (from 2015 ongoing) }\end{array}$ & 2,68 million euro \\
\hline $\begin{array}{l}\text { 6. Planned EU housing insulation } \\
\text { programme (2014-2020) }\end{array}$ & $\begin{array}{l}\text { Issued 1112 guaranties for housing loans } \\
\text { (by 31 December 2015) }\end{array}$ \\
\hline
\end{tabular}


Strategy 2020". European Union (hereafter - EU) has determined quantitative goals for member states for 2020 to reduce greenhouse gas emissions by $20 \%$, to increase energy efficiency by $20 \%$ and to ensure $20 \%$ of renewable energy resources in total gross energy end consumption (Ministru kabineta 2014b).

In 2012 end consumption of energy in buildings comprises a major part of Europe's end energy consumption $(40 \%)$, including the end energy consumption in residential buildings constitute $26 \%$ and in non-residential buildings $-14 \%$, as well as buildings sector as a whole is the largest sector that could provide energy saving.

The largest investments in the EU countries in the building sector are available from 2007, they are based on resources from EU funds and available for energy-efficiency of the buildings (Efficiency Financial Institution Group 2015).

According to the study performed by Energy Efficiency Financial Institutions Group (hereinafter - EEFIG) formed at the end of 2013 by European Commission and the United Nations Environment Programme Finance Initiative (UNEP F1), by combining public and private sector, there were identified a number of financial instruments that are potentially usable for reaching long-term objectives of energy efficiency of buildings in the EU countries.

Within framework of study EEFIG has identified the following 7 different financing instruments that are useful or very useful for energy efficiency measures in housing (including 3 mature financial instruments and 4 emerging financial instruments).

Mature financial instruments are identified as useful or very useful for energy efficiency measures in housing sector are: dedicated credit lines; rik-sharing facilities; direct and equity investments in real estate and infrastructure funds.

Dedicated energy efficiency credit lines are widely used in housing sector in many of EU countries. They tend to provide good leverage and mixing for public with private finance, can offer long maturities and low costs.

Dedicated credit lines (or soft loans) are a mechanism where public funding decreases the cost of energy efficiency building renovation loans and provides concessions on terms, such as repayment periods. The instrument are used numerous for buildings: KfW, NRW.BANK, Kredex, etc. (Efficiency Financial Institution Group 2015).

Dedicated credit lines in Latvia are implemented within the framework of Housing development lending programme Phase 2.
Risk sharing facilieties (guaranttee funds and first-loss facilieties) reduce the risks for banks and equity investors by covering part of the risk of payment default - either through a guarantee or first-loss absorption. They can be combined with dedicated credit lines and are a key instrument to grow the amount of bank lending to energy efficiency renovation.

Risk sharing has the ability to remove part of the uncertainty and first-loss risks from energy efficiency investments thereby encouraging greater amounts of private sector capital to be deployed an making energy efficiency investing attractive to larger numbers of financial institutions.

Best practice examples are: IFC's CEEP programme (Hungary, Chech republic, Estonia, Latvia, Lithuania and Slovakia), etc. (Efficiency Financial Institution Group 2015). Author concludes that the risk-sharing facilities in Latvia is now being implemented within framework of States support programme for families for purchase of the first housing when Latvian development financial institution "Altum" (hereafter - Altum) grants guarantees to commercial banks to reduce risks of commercial banks risks and to provide the opportunity to families to borrow credit from commercial bank with reduced first instalment up to $10 \%$, as well as it is planned to introduce EU funds within framework of planned EU housing insulation programme (20142020) when Altum will give guarantees to commercial banks, thereby reducing the risk in the event if the borrower will not be able to repay the housing loan (Ministru kabineta... 2014a; Ministru kabineta... 2016; Valsts kapitālsabiedrības 2016).

Direct and equity investments in real estate and infrastructure funds.

Real estate and infrastructure funds already provide a large amount of 'invisible' energy efficiency investment in the building sector. This investment takes place during a fund's investment life cycle, new developments, renovation, planned and preventive maintenance and active building management.

Real Estate investment funds are a key channel to scale up finance in energy efficiency in buildings, both through increased equity investments in the funds and through increased fund activity in energy efficiency, where it can be facilitated by strong regulatory and market frameworks (Efficiency Financial Institution Group 2015).

In Latvia the most part of investments in housing sector are invested from private companies funding.

Emerging financial instruments identified as useful or very useful for the energy efficiency 
measures in housing sector are: on-bill repayment instrument; on-tax finance instrument; energy performance contracting undertaken by public sector; citizen financing instrument.

On-Bill repayment instrument is a mechanism used to improve the creditworthiness (or seniority) of energy efficiency investments by having them repaid within the utility, bill and recovered through the existing payment collection infrastructures of utilities, or public authorities. This levers the existing payment relationship between customer and utility authority, and directly provides a "credit history" giving an accurate view of likely defaults (as customer payment histories with utilities payments are long and exhibit low default rates compared to other consumer finance).

On-bill repayment instrument has been used mostly for investments in buildings, but some schemes in the US target industry and SMEs (e.g. Massachussets).

Best practices: Green Deal in the UK; Utility obligation programmes in the USA (Efficiency Financial Institution Group 2015).

On-Bill repayment instrumnet is not implemented in Latvia.

On-tax fnance (instrument).

The U.S. Property Assessed Clean Energy (PACE) is the key example for this instrument. PACE consists in a scheme in which money is lent to a building owner to retrofit a building, but the loan is attached to the property and reimbursed through local taxes by the occupant. The fact that payments are integrated in local taxes enhances their creditworthiness, since taxes have almost zero non-payment rates in the US and they are senior to any other debt.

If the building is sold, the "loan" can be reimbursed, or taken on by new owner. Financing can be provided by the local authority or by private funds; in the latter case, the role of the public sector is to secure reimbursement by integrating it in tax collection (usually against a collection fee), while private companies are in charge of engaging building owners and signing contracts with them.

The instrument has developed mostly in the commercial buildings sector, and a small amount of residential in California and France (Efficiency Financial Institution Group 2015).

On-tax finance instrumnet is not implemented in Latvia.

Energy Performance Contracting Undertaken by Public Sector ( hereafter- public ESCO)

Public ESCO is company that formed for special aim and funded from public funds in order to manage energy efficiency investments and to en- sure specific saving of energy on the basis of ESCO contract concluded between ESCO service provider and house owner.

Public ESCO is company owned by local government that acts in accordance with principles of energy service companies by using for operation financial funds of local government and attracted financing (Efficiency Financial Institution Group 2015).

The Figure 1 shows the ESCO model financing sheme that could be useful for public ESCO and for private ESCO - ESCO company that are financed form private funds.

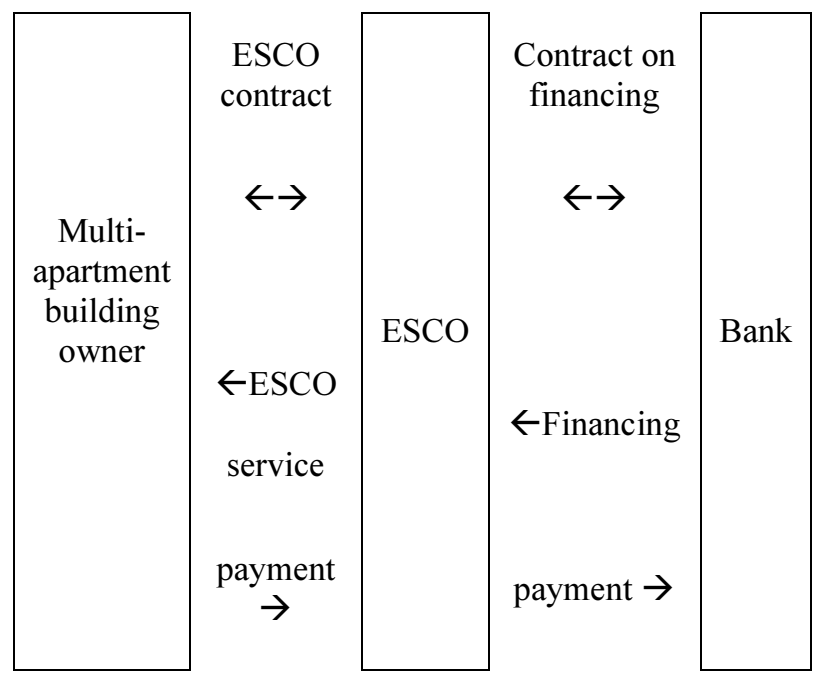

Fig. 1. Scheme of ESCO model financing (Source: developed by author by Ekonomikas ministrijas 2013)

Public ESCO could also provide multi-apartment building renovations, which are not performed by residents due to risk of recovering expenses.

This institutional model of the renovation is primarily used by local governments in Germany. For example, Freiburg by public ESCO for ten years (1990 to 1999) has reached CO2 emission reduction by $17 \%$.

Public ESCO scheme more and more is used also in new EU Member States. For example, in the Polish city Jordanów public ESCO model became the cornerstone for modernization of all energy system, providing that all savings from reduction of maintenance costs in result of renovation will be directed to the improvement of the energy system.

These examples show that public ESCO works in most effective manner when there are set longterm objectives and performance indicators to be achieved in energy efficiency in national and local levels - this can be reduction of $\mathrm{CO} 2$ or building energy consumption and annual maintenance costs by providing savings in the budget (Ekonomikas 
ministrijas 2013; Ministru kabineta 2014b; Efficiency Financial Institution Group 2015).

In Latvia public ESCO principles are applied by Ltd. "Rīgas namu pārvaldnieks" and also in some other municipalities in Latvia within renovation of multi-apartmet buildings (Ministru kabienta 2014b).

Citizen Financing instrument can be broadly split in 2 categories: Community energy finance (usually a local community using a co-operative structure) and crowdfunding (using the internet to aggregate small investors, often to fund international development projects). Both instruments are retail focused ("bottom-up") instruments currently used to fund renewables and could be used to fund energy efficiency investments.

In community energy finance projects, the investors live in the area where the investment takes place; they don't only have a financial return, but also benefit in-kind, e.g. they have access to renewable energy for free or at a lower tariff.

Crowdfunding consists in the aggregation of investors who have no direct link to the project being funded and they must trust the website offering the scheme and the projects' promoters. For energy efficiency, EEFIG can envisage community energy schemes being set-up to complete deep renovations of multifamily dwellings and/or local community facilities (schools, hospitals etc.) and the internet-based approach of crowdfunding might eventually reduce the cost of groups of "charismatic" energy efficiency project (eg. Drive to deliver competitiveness to local SMEs or for cutting edge EE technology demonstrator pilots). In Germany, there are over 500 energy co-operatives with 80,000 members which have invested up to EUR 800 million in solar plants.

\section{Evaluation of new housing financing instruments in Latvia}

On the basis of what is mentioned in sub-paragraphs 1 and 2 of the research, as well as based on the author's personal experience in work with housing policy issues during the work in Ministry of Environmental Protection and Regional Development and Ministry of Economics, the author has prepared a list or proposals of 8 new long-term housing financing instruments that would be applicable to the housing sector in Latvia. The description of each of the instrument are given in Table 2.

Table 2. Proposals of new long-term financial instruments for housing sector in Latvia (Source: developed by author)

\begin{tabular}{|c|c|}
\hline Financial instrumnet & Description of financing instruments \\
\hline $\begin{array}{l}\text { Real estate tax relief } \\
\text { instrument for complex } \\
\text { renovation }\end{array}$ & $\begin{array}{l}\text { Real estate tax relief for housing owners after housing renovation and implementation of } \\
\text { other energy efficiency measures, mainly directed to complex renovation of housing. }\end{array}$ \\
\hline $\begin{array}{l}\text { Progressive housing cred- } \\
\text { iting support instrument } \\
\text { for young families }\end{array}$ & $\begin{array}{l}\text { State of local government finances a part from remaining housing credit for young fami- } \\
\text { lies depending on the number of children in the family (for ex., along with birth of each } \\
\text { next child the state or local government finance larger part of remaining housing credit). }\end{array}$ \\
\hline $\begin{array}{l}\text { Rent relief for social } \\
\text { group housing }\end{array}$ & $\begin{array}{l}\text { Local governments finance a part from rent in local government buildings for students, } \\
\text { young families and large families (for ex., in Denmark students receive } 15 \% \text { discount } \\
\text { from rent if the student is unemployed or with small income (Kā ietaupit... 2016). }\end{array}$ \\
\hline $\begin{array}{l}\text { On-Bill Repayment } \\
\text { instrument }\end{array}$ & $\begin{array}{l}\text { Local government completely or partially finance separate measures related with housing } \\
\text { improvement (for ex., improvement of environment, replacement of separate engineering } \\
\text { communications). }\end{array}$ \\
\hline $\begin{array}{l}\text { Energy Efficiency } \\
\text { Investment Funds }\end{array}$ & $\begin{array}{l}\text { Special investments funds which are made up of public and private funds for funding } \\
\text { energy efficiency projects in order to achieve a certain energy savings. }\end{array}$ \\
\hline Green Bonds & $\begin{array}{l}\text { Proceeds from bond sales are diverted to "green projects" or projects that ensure goals of } \\
\text { renewable energy, energy-efficiency, environmental protection (for ex., a real estate de- } \\
\text { veloper (businessman) create eco-village of residential houses by issuing "green bonds" } \\
\text { and obtained proceeds are invested in construction and development of the village. JSC } \\
\text { Latvenergo in middle of } 2015 \text { issued green bonds and proceeds obtained from sale of } \\
\text { bonds are planned to be invested in the reconstruction of hydroelectric power stations, } \\
\text { protection of white storks and fish resources (Latvenergo emite... 2016). }\end{array}$ \\
\hline \multirow[t]{2}{*}{$\begin{array}{l}\text { Housing self-financing } \\
\text { instruments }\end{array}$} & $\begin{array}{l}\text { Individual funding, i.e., the person collects funds from residents or companies for a par- } \\
\text { ticular purpose (for ex., for replacement of windows in apartments, where large families } \\
\text { are living; for restoration of residential houses, which are cultural and historical objects). }\end{array}$ \\
\hline & $\begin{array}{l}\text { Crowdfunding, i.e., through Internet are collected funds for a particular purpose (for ex., } \\
\text { for installation of solar collectors in residential homes). }\end{array}$ \\
\hline
\end{tabular}


In February 2016 the authors have commenced survey of experts (from side of state government, local governments and banks) in order to clarify experts opinion regarding efficiency of long-term housing financing instruments in Latvia, including suitability of new long-term housing financing instruments to Latvian circumstances. After completing survey of experts the further researches of the author will follow.

\section{Conclusions}

As the majority of all multi-apartment buildings in Latvia were built during the Soviet era and now are in poor technical condition, and so far the investments of apartment buildings sector are not sufficient to substantially improve the overall situation in Latvia, author concluded that it is necessary to find out new possibilities to attract financial resources to the multi-apartment sector.

There are several long-term housing financial instruments that are suitable for energy efficiency measures in housing and are implemented in many EU countries, but are not implemented in Latvia. Because of this the government of Latvia should evaluate which of them and may be some new could be implemented in Latvia.

Simultaneously the state government in cooperation with local governments and private sector should look for solutions in order to support various types of housing for social groups (young families, families with more than three children, students, etc.), in order to provide them qualitative housing.

Author develop the proposals of 8 new financial long term instruments (see Table 2) for the implemented in the housing sector in Latvia. Based on that the author in February 2016 had commenced survey of experts (from side of state governments, local governments and banks) in order to clarify experts opinion regarding efficiency of long-term housing financing instruments in Latvia. After completing survey of experts the further researches of the author will follow.

\section{References}

Central Statistical Bureau database. Industry, construction, trade and services. Annual statistical data. Housing [online], [cited 20 May 2015]. Available from Internet:

http://data.csb.gov.lv/pxweb/lv/rupnbuvn/rupnbuv $\mathrm{n} \_$ikgad _ majokli/?tablelist $=$true\&rxid $=$cdcb978 c-22 b0-4 $\overline{16}$ a-aacc-aa650d3e2ce0

Efficiency Financial Institution Group. 2015. Energy Efficiency - the first fuel for the EU Economy. How to drive new finance for energy efficiency in- vestments. Final report [online], [cited 16 February 2016]. Available from Internet:

https://ec.europa.eu/energy/sites/ener/files/docume nts/Final\%20Report\%20EEFIG\%20v\%209.1\%202 4022015\%20clean\%20FINAL\%20sent.pdf

Ekonomikas ministrija. 2013. Informatīvs ziņojums par èku renovācijas finansēšanas risinājumiem [Informative report of the financial solutions for building renovation]. [Online], [cited 12 February 2015]. Available from Internet: https://em.gov.lv/ files/majokli/IZ_6.doc (in Latvian).

Economikas ministrija. 2014. Ėku siltināšana ES fondu 2014-2020. gada plānošanas periodā [Building Energy Efficiency financing in EU period 20142020]. [online], [cited 5 January 2015]. Available from Internet:

http://titania.saeima.lv/livs/saeimasnotikumi.nsf/0/ 36595dfd9d5dd487c2257ca9002fd196/\$FILE/ES $\% 20$ fondu\%202014.-2020.gada\%20\%C4\%93ku \%20energoef.fin._02.04.2014..ppt

Ekonomikas ministrija. 2015a. Piešķir papildu 700000 eiro atbalstam ğiemenēm ar bērniem mājokḷa iegādei [Allocated an additional 700,000 euros to support the families withchildren for swelling purchase]. [Online], [cited 14 Februray 2016]. Available from Internet: https://www.em.gov.lv/lv/ jaunumi/7703-pieskir-papildu-700-000-eiroatbalstam-gimenem-ar-berniem-majokla-iegadei (in Latvian)

Ekonomikas ministrija. 2015b. ES fondu īstenošanas progress Ministry of Economics [Progress in the implementation of EU funds]. [Online], [cited 17 February 2016]. Available from Internet: https://www.em.gov.lv/lv/es_fondi/istenosanas_pr ogress_

Geipele, I.; Geipele, S; Stamure, I. 2012. Finansēšanas modeļi dz̄̄vojamā fonda renovācijai Latvijā [Financing models for residential building renovation in Latvia]: Monograph. Riga: Riga Technical University.

Geipele, S. 2014. Nekustamā īpašuma tirgus vadī̌sanas sistēmas attīstība Latvijā. Promocijas darba kopsavilkums [Development of the real estate management system in Latvia]: Summary of Thesis. [Online], [cited 28 February 2015]. Available from Internet: http://www.rtu.lv/component/option,com docman/task,doc_download/gid,10992/sandasgeipeles-darba-kopsavilkums.pdf

Henilane, I. 2015a. Evaluation of housing finance policy implementation in Latvia, in the 3rd International Virtual Conference on Advances Scientific Results 25-29 May 2015, Slovakia. ISBN: 978-80-5540891-0. ISSN: 1339-9071.

Henilane, I. 2015b. Review of housing mortgage lending policy practices in Latvia, Journal of Business and Management 10: 59-69. ISSN 1691-5348.

Henilane, I. 2015c. The Evaluation of housing situation in Latvia, in Towards Smart, Sustainable and Inclusive Europe: Challenges for Future Development": 2015 proceedings of XVI Turiba Universi- 
ty International Conference, 9 May 2015, Riga, Latvia. ISSN 1691-6069.

Ikjevleva, K. 2014. Latvijas patērētāju finanšu lietpratība mājokḷu kredītu tirgū mārketinga kontekstā. Promocijas darba kopsavilkums [Latvian consumer financial literacy housing loan market marketing context. Summary of Thesis]. [Online], [cited 12 May 2015]. Available from Internet:

https://luis.lu.lv/pls/pub/luj.fprnt?l=1\&fn=F245926

210/Ksenija\%20Ijevleva\%202014.pdf

Kā ietaupīt dzìvojot Dānijā. İres maksas atlaide studentiem [How to save the money living in Denmark. Rent discounts for students]. 2016. [Online], [cited 2 January 2016]. Available from Internet: http://studystart.lv/praktiska-informacija/kaietaupit-dzivojot-danija/

Latvenergo emitē septiṇu gadu zaḷās obligācijas [JSC Latvenergo issued green bonds]. 2016. [online], [cited 4 January 2015]. Available from Internet: http://financenet.tvnet.lv/nozares/563662latvenergo_emite_septinu_gadu_zalas_obligacijas 75 miljonu eiro apmera

Ministru kabineta informatīvais ziņojums par Mājokḷu attīstības kreditēšanas programmas (II posms) īstenošanu un valsts akciju sabiedrības "Latvijas Hipotēku un zemes banka" darbību, izsniedzot galvojumus mājokḷu kredītiem [Informative report of Cabinet of Ministerrs on the Housing development lending programme (Stage II) and implementation of the State joint stock company "Latvian Mortgage and Land Bank" through the issuing of guarantees for housing loans]. 2008. [online], [cited 10 May 2015]. Available from Internet: http://tap.mk.gov.lv/lv/mk/tap/?pid=30342923\&m ode $=$ mk\&date $=2008-07-29$ (in Latvian)

Ministru kabineta 2010. gada 28. septembra noteikumi Nr. 907 Noteikumi par dzīvojamās mājas apsekošanu, tehnisko apkopi, kārtējo remontu un energoefektivitātes minimālajam prasībām [Regulations of Cabinet of Ministrers No. 907 Regarding the survey, technical servicing, current repairs and minimal requirements for energy efficiency of the residential house]. 2010. [online], [cited 10 February 2016]. Available from Internet: http://likumi.lv/doc.php?id=218831

Ministru kabineta 2014 gada noteikumi Nr. 443 "Noteikumi par valsts palīdzību dz̄ivojamās telpas iegādei un būvniecībai"“ [Regulations of Cabinet of Ministers No. 443 On state aid for purchase or construction of residential premises]. 2014a. [online], [cited 30 December 2015]. Available from Internet: http://likumi.lv/doc.php?id=268117 (in Latvian).

Ministru kabineta. 2014b. Ëku renovācijas ilgtermiña stratégija [Long term investment strategy for building renovation]. [Online], [cited 10 February 2016]. Available from Internet:

http://ec.europa.eu/energy/sites/ener/files/documen ts/2014_article4_lv_latvia.pdf (in Latvian)

Ministru kabineta noteikumi Nr. 284 "Noteikumi par darbības programmas "Infrastruktūra un pakalpojumi” papildinājuma 3.4.4.1. aktivitātes "Daudz- dzīvokḷu māju siltumnoturības uzlabošanas pasākumi" projektu iesniegumu atlases vienpadsmito un turpmākajām kārtām". [Regulations of Cabinet of Ministers No. 284 On the Operational Programme "Infrastructure and Services" Supplement 3.4.4.1. activity "Improvement of heat insulation of multi-apartment residential buildings" project selection eleventh and next rounds", project selection eleventh and next rounds"]. 2013. [online], [cited 15 May 2015]. Available from Internet: http://likumi.lv/doc.php?id=25708 (in Latvian).

Ministru kabineta noteikumu projekts "Energoefektivitātes pasākumi dz̄̄vojamās ēkās" [Regulation project Energy efficiency measures in residential buildings]. 2016. [online], [cited 15 February 2016]. Available from Internet:

https://www.em.gov.lv/lv/es_fondi/normativo_akt u projekti

Ministru kabineta rīkojums Nr. 586 „Par Mājokļu attīstības kreditēšanas programmu (II posms)", [The Cabinet of Ministers of Republic of Latvia. Order No. 586. On housing development lending programme (Stage 2)]. 2002 [online], [cited 18 February 2016]. Available from Internet: http://likumi.lv/ta/id/67556-par-majoklu-attistibaskreditesanas-programmu-ii-posms (in Latvian)

Ministry of Environmental protection and regional development. 2003. Informative report of Housing development lending Programme (Stage 1) (nonpublished).

Riga Technical University. 2013. Rokasgrāmata par ēku renovāciju Centrālbaltijas regionā [Handbook for building renovation in the Central Baltic region]. [Online], [cited 13 March 2015]. Available from Internet:

http://www.rea.riga.lv/files/Rokasgramata_par_ek u_renovaciju_Centralbaltijas_regiona.pdf

Ruza, O. 2012. Añalysis and estimations of residential real estate in the regional aspect: Scientific Work [online], [cited 5 March 2015]. Available from Internet: http://dnl.biblio.du.lv/promocijas/promocijas $\%$ 20darbs_O_Ruza.pdf

Sidelska, A. 2014. Dz̄ivojamais fonds kā regionu sociālekonomiskās attīstības elements. Promocijas darba kopsavilkums [Housing stock as an element of socio-economic developmnet of regions]: Summary of the doctoral thesis. [Online], [cited 5 April 2015]. Available from Internet:

http://lufb.llu.lv/dissertation-summary/regionaleconomics/A_Sidelska_prom_darba_kopsavilkums 2014 LLU.p.pdf

Valsts kapitālsabiedrības „Altum” mājas lapa. Mājokḷu galvojumu programma [The state joint-stock company Altum web site. Housing guarantee programme]. 2016. [Online], [cited 03 January 2016]. Available from Internet: http://www.hipo.lv/lv/attistibas_programmas/majo klu_galvojumu_programma 